\title{
Cervical dystonia is associated with a polymorphism in the dopamine (D5) receptor gene
}

\author{
M R Placzek, A Misbahuddin, K Ray Chaudhuri, N W Wood, K P Bhatia, T T Warner
}

\begin{abstract}
The objective was to assess whether polymorphisms in the dopamine receptor and transporter genes are associated with development of primary cervical dystonia. A case-control allelic association study is described of 100 patients with cervical dystonia and 100 controls using polymorphisms within D1-5 receptor and dopamine transporter genes.

No significant association was found between patient and control allele frequencies for polymorphisms in genes for the D1 to 4 receptors and dopamine transporter. Significant associations, however, were found for alleles 2 and 6 of the D5 receptor micosatellite. Carriage of allele 2 was associated with cervical dystonia, whereas allele 6 was overrepresented in the control group, implying a possible protective effect. The association with allele 6 remained significant after Bonferroni correction.

In conclusion, the finding of a significant association with an allele in the $\mathrm{D5}$ receptor gene in patients with cervical dystonia may indicate a pathogenic role of this gene (or neighbouring genes). Further studies are required to confirm this finding and to assess whether these alleles are part of distinct haplotypes associated with other polymorphisms imparting a functional effect on the D5 receptor.

(F Neurol Neurosurg Psychiatry 2001;71:262-264)
\end{abstract}

Keywords: cervical dystonia; D5 dopamine receptor; allelic association

Cervical dystonia is the commonest form of primary focal dystonia and is characterised by involuntary muscle contractions of the cervical musculature. ${ }^{1}$ The cause of focal dystonia is unknown, although there is evidence for a genetic component to its aetiology, ${ }^{2}$ particularly for cervical dystonia. ${ }^{3}$ A gene was mapped to chromosome 18p (DYT7) in a large German family in whom the phenotype was predominantly adult onset torticollis. ${ }^{4} \mathrm{~A}$ follow up study of 15 apparently sporadic cases of focal dystonia in the same region of northwest Germany suggested linkage disequilibrium for a haplotype of genetic markers from this chromosomal region, implying a founder mutation from a common ancestor. ${ }^{5} \mathrm{~A}$ second study in a larger population, however, was unable to replicate this finding. ${ }^{6}$

Evidence has accumulated to suggest that abnormalities of dopaminergic neurotransmission in the basal ganglia may be responsible for producing dystonic movements. Dopa responsive dystonia (a rare dominantly inherited form) is caused by mutations in the gene for GTPcyclohydrolase I, the rate limiting enzyme for the synthesis of tetrahydrobiopterin, a key cofactor in dopamine synthesis. ${ }^{7}$ The DYT1 gene which causes childhood onset autosomal dominant primary generalised dystonia has recently been cloned and encodes a protein called torsin A. ${ }^{8}$ The function of torsin $\mathrm{A}$ is unknown, but it is preferentially expressed in the substantia nigra pars compacta ${ }^{9}$ and may interfere with dopamine vesicle transport. ${ }^{10}$ Study of a single postmortem case of DYT-1 dystonia found normal nigral cellularity and striatal dopamine concentrations that were within the control range, except for a reduction in rostral portions of the putamen and caudate nucleus. ${ }^{11}$ This supports a functional dopaminergic deficit rather than alterations in absolute dopamine concentrations.

Further evidence for dopaminergic abnormalities in dystonia comes from the study of primates treated with the nigral toxin $\mathrm{MPTP}^{12}$ and also of patients with tardive dystonia caused by neuroleptic dopamine receptor antagonists. ${ }^{13}$ In addition, a SPECT study in patients with cervical dystonia using $\left[{ }^{123} \mathrm{I}\right]$ epidepride, a D2 receptor marker, showed evidence of reduced striatal binding. ${ }^{14}$

The aim of this study, therefore, was to examine if polymorphisms in the genes for the five dopamine receptor or dopamine transporter (DAT1) genes are associated with cervical dystonia.

\section{Patients and methods}

One hundred patients with cervical dystonia were identified from movement disorder or botulinum toxin clinics of the participating centres. Each patient had been seen by a neurologist with expertise in the field of dystonia and had been diagnosed as having primary cervical dystonia for at least 1 year. Primary dystonia was distinguished from secondary dystonia using the criteria of Marsden and 
Table 1 Dopamine receptor and transporter (DAT1) polymorphisms

\begin{tabular}{|c|c|c|}
\hline Locus & Chromosomal region & Polymorphism \\
\hline DAT1 & $5 \mathrm{p} 15.3$ & $\begin{array}{l}40 \mathrm{bp} \text { tandem repeat polymorphism at the } 3^{\prime} \\
\text { untranslated region }\end{array}$ \\
\hline D1 (D1.1) & $5 p 31-34$ & $\begin{array}{l}\text { DdeI RFLP in the } 5 \text { ' untranslated region of } \\
\text { the gene } e^{17}\end{array}$ \\
\hline D1 (D1.8) & $5 \mathrm{p} 31-34$ & PvuI RFLP within codon $421^{17}$ \\
\hline D2 & $11 \mathrm{q} 22-23$ & Microsatellite repeat at the $2 \mathrm{nd}$ intron ${ }^{18}$ \\
\hline D2 & $11 \mathrm{q} 22-23$ & TaqI A RFLP 3' flanking region of the gene ${ }^{18}$ \\
\hline D2 & $11 \mathrm{q} 22-23$ & TaqI B RFLP within the first intron ${ }^{18}$ \\
\hline D2 & $11 \mathrm{q} 22-23$ & $\begin{array}{l}\text { BstNI RFLP from the }-141 \mathrm{C} \text { Ins/Del within } \\
\text { the promoter region }{ }^{19}\end{array}$ \\
\hline D3 & $3 q 13.3$ & MscI RFLP within the first exon ${ }^{20}$ \\
\hline D4 & $11 \mathrm{p}$ & $48 \mathrm{bp}$ repeat polymorphism at the third exon ${ }^{21}$ \\
\hline D5 & $4 \mathrm{p} 15.1-15.3$ & Microsatellite (CT/GT/GA) ${ }^{22}$ \\
\hline
\end{tabular}

Harrison. ${ }^{15}$ This relies on the absence of neurological features other than dystonia and the absence of known precipitants. In most cases no other investigations were performed, except copper studies. Patients with secondary dystonia or those with affected first degree relatives were excluded. All cases were British and to avoid bias from studying a mixture of ethnic groups, were white. One hundred control subjects with a similar age range, sex, and ethnic background were collected from patients attending the Royal Free Hospital who did not have a neurological illness. The study was undertaken after ethics committee approval from the Royal Free Hospital.

Genomic DNA was extracted from lymphocytes (Nucleon BACC2 kit, Amersham) and the polymorphisms amplified by polymerase chain reaction (PCR) as previously described. The PCR was carried out in a total volume of $25 \mu \mathrm{l}$ using $100 \mathrm{ng}$ genomic DNA, 20 pmol of each primer, $200 \mu \mathrm{M}$ of each dNTP, $1.5 \mathrm{mM} \mathrm{MgCl}$, and 1 unit of Red Hot Taq with its standard buffer (Advanced Biotechnologies). D2 repeat, D2 promoter, and D4 and D5 repeat polymorphisms required an additional $10 \%$ DMSO. The 10 polymorphisms selected and method of detection are shown in table 1.

Statistical analysis was performed using a $\chi^{2}$ test. Bonferroni correction was applied where appropriate.

\section{Results}

The mean (SD) age of patients with cervical dystonia and controls was 55.5 (12.1) and 52.8 (17.5) years respectively. Mean age at onset of cervical dystonia was 44.6 (14.2) years. Sex ratios (female:male) were 1.7 for the patient group and 1.6 for the control group. There were no significant differences in the age and sex distributions between patients with cervical dystonia and the control group.

Table 2 shows the distribution of single nucleotide polymorphisms in D1-3 receptors for patients with cervical dystonia and controls. Table 3 compares the allele frequencies for microsatellites in D2, D4, D5, and DAT1 genes in cervical dystonia and control populations. No significant association was found between patient and control allele frequencies for polymorphisms in the D1 to 4 receptors and dopamine transporter. Significant associations, however, were found for alleles $2(p=0.004)$ and 6 $(p=0.0003)$ of the D5 receptor microsatellite. If corrected for multiple comparisons using the Bonferroni method only the result for D5 allele 6 remained significant. Hardy-Weinberg equilibrium was demonstrated in the control group for all polymorphisms studied.

\section{Discussion}

These data indicate an association between cervical dystonia and a polymorphism in the D5 receptor gene. For the most significant result, there is overrepresentation of allele 6 of the $\mathrm{D} 5$ receptor dinucleotide repeat within the control group compared with the cervical dystonia patient group. This may imply a protective effect of carriage of this particular allele. The converse is true for allele 2 where there is an overrepresentation in the cervical dystonia group. It is unlikely that the dinucleotide repeat within the D5 receptor confers a functional effect on the protein and any possible association may represent linkage disequilibrium with a different polymorphism within the same gene or even another gene in close proximity. Thus it is possible that there is a haplotype

Table 2 Results for allelic association for cervical dystonia and SNPs in D1-3 receptor genes

\begin{tabular}{|c|c|c|c|c|c|c|c|c|}
\hline Polymorphism & Genotype & $\begin{array}{l}\text { Torticollis } \\
\text { frequency }\end{array}$ & $\begin{array}{l}\text { Control } \\
\text { frequency }\end{array}$ & $p$ Value & Allele & $\begin{array}{l}\text { Torticollis } \\
\text { frequency }\end{array}$ & $\begin{array}{l}\text { Control } \\
\text { frequency }\end{array}$ & $p$ Value \\
\hline D1.1 & $\begin{array}{l}1 / 1 \\
1 / 2 \\
2 / 2\end{array}$ & $\begin{array}{l}21 \\
42 \\
37\end{array}$ & $\begin{array}{l}15 \\
39 \\
51\end{array}$ & 0.200 & $\begin{array}{l}1 \\
2\end{array}$ & $\begin{array}{r}84 \\
116\end{array}$ & $\begin{array}{r}69 \\
141\end{array}$ & 0.056 \\
\hline D1.8 & $\begin{array}{l}1 / 1 \\
1 / 2 \\
2 / 2\end{array}$ & $\begin{array}{r}1 \\
3 \\
101\end{array}$ & $\begin{array}{r}2 \\
5 \\
105\end{array}$ & 0.710 & $\begin{array}{l}1 \\
2\end{array}$ & $\begin{array}{r}5 \\
205\end{array}$ & $\begin{array}{r}9 \\
215\end{array}$ & 0.335 \\
\hline D2 promoter & $\begin{array}{l}1 / 1 \\
1 / 2 \\
2 / 2\end{array}$ & $\begin{array}{r}0 \\
16 \\
89\end{array}$ & $\begin{array}{r}0 \\
22 \\
78\end{array}$ & 0.213 & $\begin{array}{l}1 \\
2\end{array}$ & $\begin{array}{r}16 \\
194\end{array}$ & $\begin{array}{r}22 \\
178\end{array}$ & 0.238 \\
\hline D2 taqA & $\begin{array}{l}1 / 1 \\
1 / 2 \\
2 / 2\end{array}$ & $\begin{array}{r}4 \\
27 \\
75\end{array}$ & $\begin{array}{r}5 \\
40 \\
70\end{array}$ & 0.295 & $\begin{array}{l}1 \\
2\end{array}$ & $\begin{array}{r}35 \\
177\end{array}$ & $\begin{array}{r}50 \\
180\end{array}$ & 0.163 \\
\hline D2 taqB & $\begin{array}{l}1 / 1 \\
1 / 2 \\
2 / 2\end{array}$ & $\begin{array}{r}3 \\
22 \\
75\end{array}$ & $\begin{array}{r}3 \\
28 \\
81\end{array}$ & 0.873 & $\begin{array}{l}1 \\
2\end{array}$ & $\begin{array}{r}28 \\
172\end{array}$ & $\begin{array}{r}34 \\
190\end{array}$ & 0.731 \\
\hline D3 & $\begin{array}{l}1 / 1 \\
1 / 2 \\
2 / 2\end{array}$ & $\begin{array}{l}44 \\
49 \\
10\end{array}$ & $\begin{array}{r}51 \\
52 \\
7\end{array}$ & 0.636 & $\begin{array}{l}1 \\
2\end{array}$ & $\begin{array}{r}137 \\
69\end{array}$ & $\begin{array}{r}154 \\
66\end{array}$ & 0.438 \\
\hline
\end{tabular}


Table 3 Allelic association between cervical dystonia and microsatellites in dopamine receptor and DAT genes

\begin{tabular}{|c|c|c|c|c|}
\hline Polymorphism & Allele & $\begin{array}{l}\text { Torticollis } \\
\text { frequency }\end{array}$ & $\begin{array}{l}\text { Control } \\
\text { frequency }\end{array}$ & $p$ Value \\
\hline \multirow[t]{5}{*}{ DAT1 } & 7 & 0 & 1 & 0.356 \\
\hline & 8 & 1 & 0 & 0.278 \\
\hline & 9 & 48 & 58 & 0.875 \\
\hline & 10 & 153 & 178 & 0.841 \\
\hline & 11 & 2 & 3 & 0.788 \\
\hline \multirow[t]{5}{*}{ D2 } & 0 & 1 & 0 & 0.331 \\
\hline & 1 & 43 & 43 & 0.761 \\
\hline & 2 & 105 & 110 & 0.266 \\
\hline & 3 & 30 & 21 & 0.261 \\
\hline & 4 & 33 & 26 & 0.457 \\
\hline \multirow[t]{8}{*}{ D4 } & 3 & 18 & 18 & 0.975 \\
\hline & 4 & 12 & 7 & 0.231 \\
\hline & 5 & 131 & 129 & 0.731 \\
\hline & 6 & 2 & 3 & 0.661 \\
\hline & 7 & 0 & 1 & 0.319 \\
\hline & 8 & 35 & 42 & 0.402 \\
\hline & 10 & 2 & 1 & 0.556 \\
\hline & $>10$ & 0 & 1 & 0.319 \\
\hline \multirow[t]{12}{*}{ D5 } & 1 & 0 & 2 & 0.154 \\
\hline & 2 & 13 & 2 & 0.004 \\
\hline & 3 & 15 & 15 & 0.977 \\
\hline & 4 & 31 & 25 & 0.410 \\
\hline & 5 & 90 & 83 & 0.536 \\
\hline & 6 & 8 & 29 & 0.0003 \\
\hline & 7 & 8 & 6 & 0.599 \\
\hline & 8 & 9 & 9 & 0.983 \\
\hline & 9 & 9 & 8 & 0.821 \\
\hline & 10 & 12 & 11 & 0.849 \\
\hline & 11 & 1 & 7 & 0.031 \\
\hline & 12 & 6 & 3 & 0.319 \\
\hline
\end{tabular}

associated with allele 2 that confers susceptibility to developing cervical dystonia and a "protective" haplotype associated with allele 6 .

D5 belongs to the D1-like class of dopamine receptors (D1/D1A, D1B) that stimulate adenlyl cyclase activity. For this reason it is interesting to note the trend towards significance for association with the D1.1 allele $1(\mathrm{p}=0.056)$. D1 receptors are expressed in the striatum as well as cortex and limbic structures. D5 receptor mRNA has been demonstrated in human substantia nigra pars compacta as well as the neocortex and hippocampus. ${ }^{23}$ Thus D5 receptor dysfunction could influence basal ganglia dopaminergic pathways. If there is an association between $\mathrm{D} 1 / \mathrm{D} 5$ receptors for cervical dystonia it is possible that this effects the direct pathway in the cortico-basal ganglia-cortex motor loops leading to overactivity and a susceptibility for developing cervical dystonia.

Evidence to support a possible dopaminergic susceptibility for developing focal dystonia comes from recent work on a rat model of blepharospasm, a focal dystonia of the extraocular muscles. ${ }^{24}$ Rats were given a striatal injection of $\mathrm{OH}$-dopa, leading to a dopaminergic lesion which produced excitability of the trigeminal nerve blink reflex. This in itself did not produce blepharospasm, but a subsequent lesion to the facial nerve, weakening the orbicularis oculi, led to the development of blepharospasm. Thus it is possible that a functional dopaminergic genetic susceptibility may subsequently lead to the development of cervical dystonia after appropriate secondary stimuli.

For all allelic association studies it is critical that any possible allelic association is confirmed in an independent cohort and control group, and we are currently undertaking this.
In addition, we are searching for other single nucleotide polymorphisms or polymorphisms within the D1 and D5 genes to see whether it is possible to create a haplotype associated with alleles 2 and 6 of the D 5 repeat and the D1.1 single nucleotide polymorphism. This may provide evidence for linkage disequilibrium to a different functional polymorphism or mutation in these genes, or even to a gene located in close proximity.

We are grateful to The Dystonia Society for financial assistance, and all the patients who participated in this study.

1 Dauer WT, Burke RE, Greene P, et al. Current concepts on the clinical features, aetiology and management of idiopathic cervical dystonia. Brain 1998;121:547-60.

2 Waddy HM, Fletcher NA, Harding AE, et al. A genetic study of idiopathic focal dystonia. Ann Neurol 1991;29: $320-4$.

3 Uitti RJ, Maraganore DM. Adult onset familial cervical dystonia: report of a family including monozygotic twins. Mov Disord 1993;8:489-94.

4 Leube B, Rudnicki D, Ratzlaff $\mathrm{T}$, et al. Idiopathic torsion dystonia: assignment of a gene to chromosome $18 \mathrm{p}$ in a German family with adult onset, autosomal dominant inheritance and purely focal distribution. Hum Mol Genet

5 Leube B, Hendgren T, Kessler KR, et al. Sporadic focal dystonia in northwest Germany: molecular basis on chromosome 18p. Ann Neurol 1997;42:111-14.

6 Klein C, Ozelius LJ, Hagenah J, et al. Search for a founder mutation in idiopathic focal dystonia from northern Germany. Am f Hum Genet 1998;63:1777-82.

7 Ichinose $\mathrm{H}$, Ohye $\mathrm{T}$, Takahashi $\mathrm{E}$, et al. Hereditary progressive dystonia with marked diurnal fluctuation caused by mutations in the GTP cyclohydrolase I gene. Nature Genet 1994;8:236-42.

8 Ozelius L, Hewett J, Page C, et al. The early onset torsion dystonia gene (DYT1) encodes and ATP-binding protein. Nature Genet 1997;17:40-8.

9 Augood SJ, Martin DB, Ozelius LO, et al. Distribution of mRNAs encoding TorsinA and TorsinB in normal adult mRNAs encoding TorsinA and TorsinB

10 Hewett J, Gonzalez-Agosti C, Slater D, et al. Mutant torsin $\mathrm{A}$, responsible for early-onset torsion dystonia, forms membrane inclusions in cultured neural cells. Hum Mol Genet 2000;9:1403-13

11 Furukawa Y, Hornykiewicz O, Fahn S, et al. Striatal dopamine in early-onset primary torsion dystonia with the DYT1 mutation. Neurology 2000;54:1193-5.

12 Perlmutter JS, Tempel LW, Black KJ, et al. MPTP induces dystonia and parkinsonism: clues to the pathophysiology of dystonia. Neurology 1997;49:1432-8.

13 Burke R, Fahn S, Jankovic J, et al. Tardive dystonia: late-onset and persistent dystonia caused by anti-psychotic drugs. Neurology 1982;32:1335-46.

14 Naumann M, Pirker W, Reiners K, et al. Imaging the pre- and post-synaptic side of striatal dopaminergic synapses in
idiopathic cervical dystonia: A SPECT study using $\left[{ }^{123} \mathrm{I}\right]$ Epidepride and $\left.{ }^{123} \mathrm{I}\right]$ beta-CIT. Mov Disord 1998;13:319-23.

15 Marsden CD, Harrison MJG. Idiopathic torsion dystonia Marsden CD, Harrison $\mathrm{MJG}$. Idiopathic torsion dystonia
(dystonia musculorum deformans): a review of 42 patients. (dystonia musculorum defo

16 Le Couteur DG, Leighton PW, McCann SJ, et al. Association of a polymorphism in the dopaminetransporter gene with Parkinson's disease. Mov Disord 1997;12:760-3

17 Cichon S, Nothen MM, Erdmann J, et al. Detection of four polymorphic sites in the human D1 receptor gene (DRD1). Hum Mol Genet 1994;3:209.

18 Hauge XY, Grandy DK, Eubanks JH, et al. Detection and characterisation of additional DNA polymorphisms in the dopamine D2 receptor. Genomics 1991;10:527-30.

19 Arinami T, Gao M, Hamaguchi $\mathrm{H}$, et al. A functional polymorphism in the promoter region of the dopamine D2 receptor is associated with schizophrenia. Hum Mol Genet receptor is associat

20 Lannfelt L, Sokoloff P, Martres MP, et al. Amino acid substitution in the dopamine D3 receptor as a useful polymorphism for investigating psychiatric disorders. Psychiatr Genet 1992;2:249-56.

21 Lichter JB, Barr C, Kennedy J, et al. A hypervariable segment in the human dopamine receptor D4 (DRD4) gene. Hum Mol Genet 1993;3:767-73.

22 Sherrington R, Mankoo B, Attwood J, et al. Cloning of the human dopamine $\mathrm{D} 5$ receptor gene and identification of a highly polymorphic microsatellite for the DRD 5 locus that show tight linkage to the chromosome $4 \mathrm{p}$ reference marker RAF1P1. Genomics 1993;18:423-5.

23 Beischlag TV, Marchese A, Meador-Woodruff JH, et al. The human dopamine D 5 receptor gene: cloning and characterisation of the 5'-flanking and promoter region. Biochemistry 1995;34:5960-70.

24 Schicatano EJ, Basso MA, Eringer C. Animal model explains the origin of the cranial dystonia benign essential blepharospasm. F Neurophysiol 1997;77:2842-6. 